\title{
First Observation of Hemoglobin San Diego, a High Oxygen Affinity Hemoglobin Variant, in Turkey
}

\author{
Türkiye'de Gözlenen Illk Hemoglobin San Diego (Oksijene IIlgisi Yüksek Bir Hemoglobin \\ Varyantı) Olgusu
}

\author{
Ebru Yılmaz Keskin ${ }^{1}$ Ali Fettah², Ana Catarina Oliveira ${ }^{3}$, Şule Toprak², Andreia Lopes ${ }^{3}$, Celeste Bento ${ }^{3,4}$ \\ ${ }^{1}$ Süleyman Demirel University Faculty of Medicine, Department of Pediatric Hematology and Oncology, Isparta, Turkey \\ ${ }^{2}$ Dr. Sami Ulus Maternity and Children's Training and Research Hospital, Clinic of Pediatric Hematology and Oncology, Ankara, Turkey \\ ${ }^{3}$ Coimbra University, Centro Hospital, Clinic of Hematology, Coimbra, Portugal \\ ${ }^{4} \mathrm{CIAS}$, Coimbra University, Department of Life Sciences, Coimbra, Portugal
}

To the Editor,

Congenital erythrocytosis (CE) or congenital polycythemia represents a rare clinical entity. High oxygen affinity hemoglobin $\mathrm{Hb})$ variants are a very rare cause of secondary CE. In 1966, Charache et al. [1] published the first case of a $\mathrm{Hb}$ variant associated with erythrocytosis, Hb Chesapeake. Since then, more than 220 variants with high oxygen affinity have been discovered and the autosomal dominant inheritance has been confirmed [2].

Many $\mathrm{Hb}$ variants have been reported so far from Turkey $[3,4,5]$. We report herein the first observation of Hb San Diego, a high oxygen affinity $\mathrm{Hb}$ variant, from Turkey in a case of CE.

Case: A 15-year-old female patient residing in Kastamonu, Turkey, and examined due to the complaints of occasional headache, fatigue, dizziness, nausea, and chest pain was found to have an elevated $\mathrm{Hb}$ level. Erythrocytosis was also present in other family members, including her father and paternal grandmother (Figure 1). Both the father and grandmother had a history of several phlebotomies.

Laboratory data are presented in Table 1. Serum biochemistry, abdominal ultrasonography, and echocardiographic examinations were all unremarkable. In addition to her family history consistent with a disorder transmitted autosomal dominantly, the finding of reduced P50 suggested the presence of a high oxygen affinity $\mathrm{Hb}$. $\mathrm{Hb}$ electrophoresis performed with the high-performance liquid chromatography (HPLC) method with the device ZIVAK using the Hb Variant Whole Blood HPLC Analysis Kit yielded no abnormal $\mathrm{Hb}$ variant. The examination was repeated with Trinity Biotech's Premier Hb9210 resolution method and displayed the presence of a $\mathrm{Hb}$ variant in both the patient and her father (Figure 1). Sanger sequencing analysis confirmed the associated mutation in the $\beta$-globin gene [Hb San Diego; $\beta 109(\mathrm{G} 11) \mathrm{Val} \rightarrow$ Met] (Figure 2).
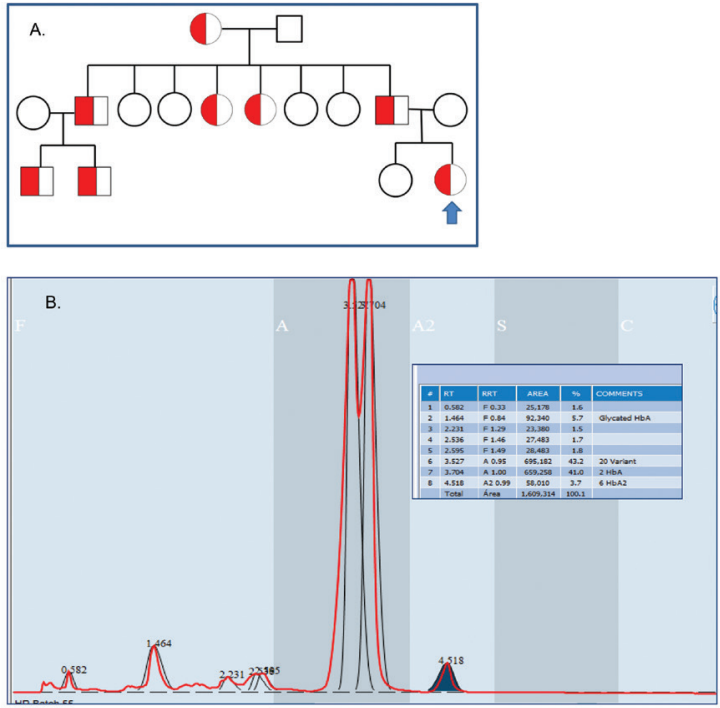

Figure 1. A) Pedigree of the family with erythrocytosis and hemoglobin $(\mathrm{Hb})$ San Diego, illustrating dominant mode of inheritance of erythrocytosis. The propositus is indicated with an arrow; B) high-performance liquid chromatography (premier Hb9210 resolution) showing the presence of Hb San Diego.

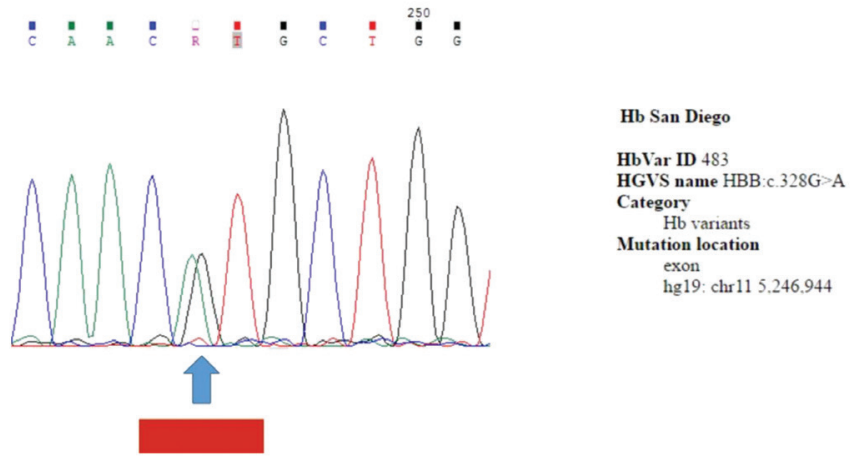

Figure 2. Identification of hemoglobin San Diego in $\beta$-globin gene by Sanger sequencing analysis in the index case.

HbVar: Hemoglobin variant. 


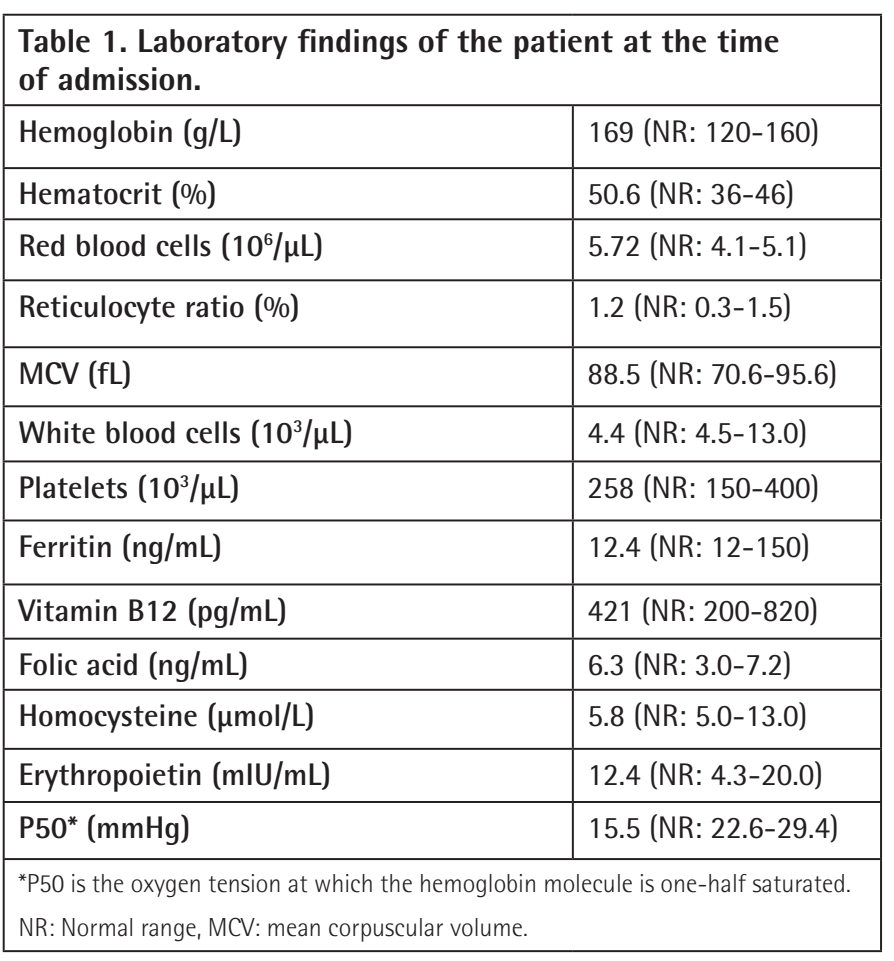

Erythrocytosis may be the clinical manifestation of the presence of a high oxygen affinity $\mathrm{Hb}$. $\mathrm{Hb}$ San Diego was first reported in 1974 in a Filipino family [6]. Thereafter, it has been described in subjects of different origins $[7,8,9,10,11,12]$. Our case represents the first one of Hb San Diego in Turkey. Although Hb San Diego was described as electrophoretically silent [6], it could be clearly identified using the new Trinity Biotech Premier Hb9210 resolution technology.

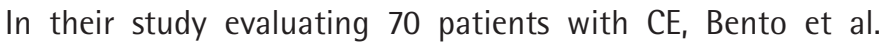
[11] sequenced all the genes described as associated with CE and erythrocytosis molecular etiology was identified in only $25(36 \%)$ subjects, a high oxygen affinity $\mathrm{Hb}$ being the cause in $14(56 \%)$ of these 25 subjects. Determination of the P50 value, calculated easily from fresh venous blood gas samples, is a practical and useful test, and a decreased value may direct clinicians to order examinations regarding a $\mathrm{Hb}$ variant [12]. Some high oxygen affinity Hbs are electrophoretically silent but their identification can be rapidly done by direct sequencing of the globin genes (HBB and HBA).

Management of CE caused by a high oxygen affinity $\mathrm{Hb}$ should be personalized, and it should primarily depend on smoking cessation and physical activity. Phlebotomy and platelet aggregation inhibitors' prescription should be evaluated carefully, and blood donation is not advised [2].
Keywords: Abnormal hemoglobins, Hemoglobin San Diego, Hemoglobin variant

Anahtar Sözcükler: Anormal hemoglobinler, Hemoglobin San Diego, Hemoglobin varyantı

Conflict of Interest: The authors of this paper have no conflicts of interest, including specific financial interests, relationships, and/or affiliations relevant to the subject matter or materials included.

\section{References}

1. Charache S, Weatherall DJ, Clegg JB. Polycythemia associated with a hemoglobinopathy. J Clin Invest 1966;45:813-822.

2. Mangin 0. High oxygen affinity hemoglobins. Rev Med Interne 2017;38:106112.

3. Altay Ç. Abnormal hemoglobins in Turkey. Turk J Haematol 2002;19:63-74.

4. Akar E, Akar N. A review of abnormal hemoglobins in Turkey. Turk J Haematol 2007;24:143-145.

5. Akar N. An updated review of abnormal hemoglobins in the Turkish population. Turk J Haematol 2014;31:97-98.

6. NutePE, Stamatoyannopoulos G, Hermodson MA, Roth D. Hemoglobinopathic erythrocytosis due to a new electrophoretically silent variant, Hemoglobin San Diego (B109 (G11) Val $\rightarrow$ Met). J Clin Invest 1974;53:320-328.

7. González Fernández FA, Villegas $A$, Ropero $P$, Carreño MD, Anguita E, Polo $M$, Pascual $A$, Henández $A$. Haemoglobinopathies with high oxygen affinity. Experience of Erythropathology Cooperative Spanish Group. Ann Hematol 2009;88:235-238.

8. Loukopoulos D, Poyart C, Delanoe-Garin J, Matsis C, Arous N, Kister J, Loutradi-Anagnostou A, Blouquit Y, Fessas P, Thillet J, Rosa F, Galacteros F. Hemoglobin San Diego/beta zero thalassemia in a Greek adult. Hemoglobin 1986;10:143-159.

9. Coleman MB, Adams LG 3rd, Walker AM, Plonczynski MW, Harrell AH, Kark JA, Schechter GP. Hb San Diego [beta 109 (G11) Val-->Met] in an Iranian: further evidence for a mutational hot spot at position 109 of the betaglobin gene. Hemoglobin 1993;17:543-545.

10. Miniero R, Pullano MN, Oliverio AC, Benevento C, Madonna G, Altomare F, Giancotti L. Two Calabrian children with Hemoglobin San Diego. Child 2012;1:11.

11. Bento C, Percy MJ, Gardie B, Maia TM, van Wijk R, Perrotta S, Della Ragione F, Almeida $H$, Rossi C, Girodon $F$, Aström M, Neumann D, Schnittger $S$, Landin B, Minkov M, Randi ML, Richard S, Casadevall N, Vainchenker W, Rives $\mathrm{S}$, Hermouet $\mathrm{S}$, Ribeiro ML, McMullin MF, Cario H; ECE-Consortium, Chauveau A, Gimenez-Roqueplo AP, Bressac-de-Paillerets B, Altindirek D, Lorenzo F, Lambert F, Dan H, Gad-Lapiteau S, Catarina Oliveira A, Rossi C, Fraga C, Taradin G, Martin-Nuñez G, Vitória H, Diaz Aguado H, Palmblad J, Vidán J, Relvas L, Ribeiro ML, Luigi Larocca M, Luigia Randi M, Pedro Silveira M, Percy M, Gross M, Marques da Costa R, Beshara S, Ben-Ami T, Ugo V; ECEConsortium. Genetic basis of congenital erythrocytosis: mutation update and online databases. Hum Mutat 2014;35:15-26.

12. Bento $C$, Almeida $H$, Maia TM, Relvas $L$, Oliveira AC, Rossi C, Girodon $F$, Fernandez-Lago C, Aguado-Diaz A, Fraga C, Costa RM, Araujo AL, Silva J, Vitoria $H$, Miguel N, Silveira MP, Martin-Nuñez G, Ribeiro ML. Molecular study of congenital erythrocytosis in 70 unrelated patients revealed a potential causal mutation in less than half of the cases (Where is/are the missing gene(s)?). Eur J Haematol 2013;91:361-368. 